\begin{tabular}{|c|c|}
\hline $\begin{array}{l}\text { MOSOL } \\
\text { MANAUEMEN } \\
\text { KEWIBAUSAHAAN }\end{array}$ & $\begin{array}{rr}\text { p-ISSN 1858-1048 } & \begin{array}{r}\text { e-ISSN 2654-9247 } \\
\text { http://ejurnal.stieipwija.ac.id/index.php/jmk }\end{array} \\
\text { DOI: } \underline{\text { http://dx.doi.org/10.33370/imk.v17i2.485 }} \\
\text { Jurnal Manajemen Kewirausahaan Vol. 17 No. 02 - Des } 2020 \\
\text { Submit: 25 Nov 2020; Review: 2 Des 2020; Publish: } 28 \text { Des } 2020\end{array}$ \\
\hline
\end{tabular}

\title{
LOYALITAS MAHASISWA: DAMPAK PERSEPSI BAURAN KOMUNIKASI TERHADAP PROSES KEPUTUSAN MEMILIH PERGURUAN TINGGI
}

\section{(STUDENT LOYALTY: THE IMPACT OF PERCEPTIONS OF COMMUNICATION MIX ON THE DECISION PROCESS TO CHOOSE HIGHER EDUCATION)}

\author{
Oleh: \\ Heru Mulyanto'); Agnes Ashanti'2); Meli Andriyani'3); Arief Teguh Nugroho4) \\ drherumulyanto@gmail.com ${ }^{1)}$; agnes.ashnt@gmail.com ${ }^{2}$; myodah@gmail.com $^{3)}$; arieftgiyonk@gmail.com ${ }^{4}$ \\ Sekolah Tinggi Ilmu Ekonomi IPWI Jakarta ${ }^{1,2,3)}$; Universitas Pelita Bangsa Bekasi4)
}

\begin{abstract}
ABSTRAK
Penelitian ini bertujuan untuk mengetahui pengaruh persepsi bauran komunikasi (penyerapan informasi mahasiswa atas iklan, promosi penjualan, personal selling, dan publisitas yang dilakukan perguruan tinggi) terhadap proses keputusan mahasiswa memilih perguruan tinggi serta dampaknya pada loyalitas mahasiswa. Data penelitian diperoleh dari kuesioner yang disebarkan kepada 130 responden yaitu mahasiswa yang ada di wilayah Bekasi. Structural Equation Modelling (SEM) digunakan sebagai alat analisis menggunakan AMOS 23. Penelitian menghasilkan temuan bahwa penyerapan informasi atas bauran komunikasi berpengaruh terhadap proses keputusan mahasiswa dalam memilih perguruan tinggi dan berdampak pada loyalitas mahasiswa di wilayah Bekasi. Penyerapan informasi promosi penjualan dan publisitas berpengaruh positif terhadap proses keputusan memilih perguruan tinggi. Penyerapan informasi iklan dan personal selling tidak berpegaruh terhadap proses keputusan memilih perguruan tinggi. Proses keputusan memilih perguruan tinggi berpengaruh terhadap loyalitas mahasiswa.
\end{abstract}

Kata kunci: Bauran Komunikasi; Iklan; Loyalitas; Personal Selling; Promosi Penjualan; Proses Keputusan; Publisitas

\begin{abstract}
This study aims to determine the effect of communication mix perceptions (absorption of student information on advertisements, sales promotions, personal selling, and publicity conducted by higher education institutions) on the decision process of students choosing higher education institutions and their impact on student loyalty. The research data were obtained from a questionnaire distributed to 130 respondents, namely students in the Bekasi area. Structural Equation Modeling (SEM) was used as an analytical tool using AMOS 23. The study found that the absorption of information on the communication mix had an effect on the student's decision process in choosing a university and had an impact on student loyalty in the Bekasi area. The absorption of sales promotion information and publicity has a positive effect on the decision process to choose a university. The absorption of advertising and personal selling information does not affect
\end{abstract}

Jurnal Manajemen Kewirausahaan Vol. 17 No. 02 - Desember 2020

LP2M Sekolah Tinggi Ilmu Ekonomi IPWI Jakarta 
the decision process to choose a university. The decision process to choose a university has an effect on student loyalty.

Keywords: Advertisement; Communication Mix; Decision Process; Loyalty; Personal Selling; Publicity; Sales Promotion

\section{PENDAHULUAN}

Perguruan Tinggi adalah lembaga pendidikan yang tertinggi di dalam sistem pendidikan nasional di semua negara. Perguruan tinggi memiliki posisi strategis dalam pembangunan sebuah bangsa sehingga jumlah perguruan tinggi di sebuah negara akan mendongkrak daya saing negara tersebut. Di Indonesia, jumlah perguruan tinggi semakin banyak terutama dengan semakin banyaknya Perguruan Tinggi Swasta (PTS). Hal ini mau tidak mau memunculkan persaingan di kalangan perguruan tinggi untuk mendapat tempat di hati calon mahasiswa dan juga mahasiswa yang telah aktif mengikuti kegiatan perkuliahan. Namun demikian hal ini bukanlah perkara yang mudah karena banyak perguruan tinggi yang kesulitan menjaring mahasiswa baru walaupun berbagai komunikasi telah dijalankan untuk bisa memperkenalkan diri kepada calon mahasiswa. Selain itu, mahasiswa yang sudah memilih sebuah perguruan tinggi belum tentu mau merekomendasikan perguruan tinggi tempat kuliah kepada teman, saudara, kerabat, dan komunitasnya. Bahkan ada juga mahasiswa yang tidak bertahan dan keluar dari perguruan tinggi yang telah dipilihnya.

Kesediaan mahasiswa untuk merekomendasikan kepada pihak lain diperlukan untuk kelangsungan hidup dan berkembangnya suatu perguruan tinggi. Kesediaan mahasiswa untuk merekomendasikan merupakan gambaran yang lebih tepat yang menunjukkan adanya loyalitas mahasiswa dibandingkan pembelian ulang. Hal tersebut menunjukkan bahwa loyalitas merupakan hal yang penting dan dapat diupayakan oleh perguruan tinggi sebagai penyelenggara pendidikan (Wantara, 2015).

Loyalitas muncul karena banyak hal seperti keputusan pembelian (Susdiarto,
2013), citra merek dan kepuasan (Kasuma Dewi, 2012), bauran pemasaran (Permatasari, 2014). Keputusan memilih merupakan salah satu faktor paling potensial (Susdiarto, 2013; Fajarsih, 2019) dimana keputusan memilih digambarkan sebagai keputusan pembelian. Hal yang sama terjadi di dunia pendidikan dalam hal ini loyalitas mahasiswa di wilayah Bekasi dimana cepat lambatnya proses awal dalam memutuskan untuk memilih perguruan tinggi sebagai tempat kuliah menjadi indikasi yang kuat dalam mendorong loyalitas mahasiswa.

Proses keputusan mahasiswa memilih perguruan tinggi dapat cepat jika informasi tentang perguruan tinggi tersebut sampai kepada calon mahasiswa. Informasi tersebut dapat diterima jika perguruan tinggi mampu mengkomunikasikan dirinya kepada calon konsumen (Permatasari, 2014; Rahmawati, 2018). Banyak cara yang dapat digunakan oleh perguruan tinggi untuk mengkomunikasikan diri yaitu dengan berbagai bentuk bauran komunikasi yang antara lain berupa iklan, promosi penjualan, personal selling, dan publisitas.

Pengaruh bauran komunikasi (penyerapan informasi dari iklan, promosi penjualan, personal selling, dan publisitas) terhadap proses keputusan serta dampaknya terhadap loyalitas dalam penelitian ini sebagai sebuah model utuh memiliki nilai lebih karena pada penelitian sebelumnya sebagian besar dianalisis dengan model sederhana dan satu tingkat yaitu hanya promosi terhadap keputusan (Rahmawati, 2018) terpisah dengan pengaruh keputusan terhadap loyalitas sebagai model tersendiri (Hermawan, 2015). Pada penelitian lainnya, bauran promosi tidak dikaitkan dengan keputusan pembelian melainkan terhadap minat (Sitorus, 2014). 


\section{TUJUAN PENELITIAN}

Penelitian

bertujuan pengaruh

untuk bauran komunikasi (persepsi calon mahasiswa atas iklan, promosi penjualan, personal selling, dan publisitas yang dilakukan perguruan tinggi) terhadap proses keputusan memilih perguruan tinggi serta dampaknya terhadap loyalitas.

\section{TELAAH LITERATUR DAN PENGEMBANGAN HIPOTESIS Persepsi Iklan dan Proses Keputusan}

Iklan dilakukan perguruan tinggi dalam rangka mengkomunikasikan atau memberi informasi tentang keunggulan, atau keunggulan suatu produk atau organisasi secara tidak langsung, yang disusun sedemikian rupa sehingga menimbulkan rasa menyenangkan yang akan mengubah pikiran seseorang untuk melakukan pembelian (Tjiptono dalam Rahman, 2012:20). Iklan merupakan variabel yang paling berpengaruh terhadap peningkatan jumlah mahasiswa (Dharmawansyah, 2014). Adanya pengaruh iklan terhadap keputusan pembelian juga terdapat pada penelitian yang lainnya (Afnina, 2011; Maulida, 2011; Kasumadewi, 2012). Oleh karena itu dapat diduga, bahwa persepsi iklan berpengaruh terhadap proses keputusan mahasiswa memilih perguruan tinggi.

H1: Persepsi iklan berpengaruh terhadap proses keputusan mahasiswa memilih perguruan tinggi.

\section{Persepsi Promosi Penjualan dan Proses Keputusan}

Promosi penjualan dilakukan perguruan tinggi dengan memberikan insentif khusus atau program yang mendorong konsumen untuk membeli produk tertentu atau pelayanan biasanya digunakan bersama dengan iklan atau program penjualan langsung (Grewel dan Levy, 2014:572). Promosi penjualan berpengaruh positif dan signifikan terhadap sikap konsumen dalam mengambil keputusan (Afnina, 2011; Sitorus, 2014; Fahruddin, 2015). Oleh karena itu dapat diduga bahwa persepsi promosi penjualan berpengaruh positif terhadap keputusan mahasiswa memilih perguruan tinggi.

H2: Persepsi promosi penjualan berpengaruh positif terhadap keputusan mahasiswa memilih perguruan tinggi.

\section{Persepsi Personal Selling dan Proses Keputusan}

Personal selling dilakukan dalam rangka memperkenalkan dan mengkomunikasikan suatu produk atau organisasi kepada calon pelanggan secara langsung (tatap muka) antara penjual dan calon pelanggan sehingga dapat menggugah calon konsumen untuk mencoba membeli (Tjiptono, 2008: 224). Personal selling memiliki pengaruh secara positif dan signifikan terhadap keputusan pembelian (Maulida, 2011; Adeputra \& Rachmawati, 2017; Dharmawansyah, 2014). Berdasarkan uraian di atas dapat diduga bahwa persepsi personal selling berpengaruh terhadap keputusan mahasiswa memilih perguruan tinggi.

H3: Persepsi personal selling berpengaruh terhadap keputusan mahasiswa memilih perguruan tinggi.

\section{Persepsi Publisitas dan Proses Keputusan}

Publisitas dilakukan sebagai upaya untuk mempengaruhi sikap, perasaan, dan pendapat pelanggan, non pelanggan, pemegang saham, pemasok, karyawan, personal, politik tentang organisasi yang sifatnya tak berbayar melalui media massa dalam bentuk pemberitaan dan pastinya para pemasar menginginkan pemberitaan positif (J. Paul Peter dan James H. Donnelly, 2008:112). Publisitas memiliki pengaruh yang signifikan terhadap keputusan pembelian (Fajarsih, 2019). Afnina (2011) menghasilkan temuan bahwa publisitas dalam bentuk hubungan masyarakat berpengaruh terhadap keputusan. Meskipun Fahruddin (2015) meneliti pengaruhnya terhadap proses keputusan bukan keputusannya. Penelitian lainnya juga banyak yang menghasilkan temuan adanya pengaruh publisitas terhadap keputusan (Rohman, 2014; Dharmawansyah, 2014; Adeputra \& Rachmawati, 2017) pada obyek yang 
berbeda-beda. Berdasarkan uraian di atas dapat diduga bahwa persepsi publisitas berpengaruh terhadap proses keputusan mahasiswa memilih perguruan tinggi.

H4: Persepsi publisitas berpengaruh terhadap proses keputusan mahasiswa memilih perguruan tinggi.

\section{Proses Keputusan Memilih dan Loyalitas}

Keputusan pembelian (diasumsikan sebagai keputusan memilih) merupakan perilaku keputusan pembelian mengacu pada perilaku pembelian akhir dari konsumen, baik individual, maupun rumah tangga yang membeli barang dan jasa untuk konsumsi pribadi (Kotler \& Armstrong, 2014:158). Berdasarkan penelitian terdahulu yang dikemukakan oleh Hermawan (2015) dimana keputusan pembelian memiliki pengaruh yang signifikan terhadap loyalitas. Aep Nurbani (2019) menghasilkan temuan bahwa kepercayaan mempengaruhi loyalitas. Penelitian lainnya juga banyak yang menghasilkan temuan adanya pengaruh keputusan memilih terhadap loyalitas (Adeputra \& Rachmawati, 2017; Susdiarto, 2013; Hariyana 2013). Berdasarkan uraian di atas dapat diduga bahwa proses keputusan memilih berpengaruh terhadap loyalitas mahasiswa.

H5: Proses keputusan memilih berpengaruh terhadap loyalitas mahasiswa.

\section{METODE PENELITIAN}

Penelitian dilakukan terhadap mahasiswa yang bertempat tinggal di Bekasi tanpa memandang perguruan tinggi tempat kuliah. Pelaksanaan penelitian dari bulan Januari dan Februari 2020 atau dua bulan.

Penelitian menggunakan pendekatan kuantitatif yaitu explanatory research tipe kausal. Enam variabel penelitian yaitu terdiri dari empat variabel independen, satu variabel intervening dan satu variabel dependen. Variabel independen terdiri dari iklan, promosi penjualan, personal selling, dan publisitas. Variabel dependen terdiri dari keputusan memilih dan loyalitas.

Kuesioner tertutup 5 (lima) skala interval dikembangkan dari indikator masing-masing variabel penelitian digunakan untuk pengambilan data. Kuesioner diberikan kepada 130 mahasiswa yang bertempat tinggal di wilayah Bekasi sebagai responden penelitian.

Data yang terkumpul dari hasil kuesioner dianalisis untuk mengetahui pengaruh variabel independen terhadap variabel intervening dan dampaknya pada variabel dependen. Oleh karena itu lingkup penelitian ini adalah menguji pengaruh bauran komunikasi (penyerapan informasi oleh mahasiswa dari iklan, promosi penjualan, personal selling, dan publisitas yang dilakukan perguruan tinggi) terhadap proses keputusan dan loyalitas mahasiswa.

Analisis data dilakukan dengan Model Persamaan Struktural (Structural Equation Modelling atau SEM). SEM digunakan dalam penelitian ini mengingat SEM mampu mengukur faktor dan pengaruh antar variabel dalam model utuh secara serempak (bersamaan). Pada penelitian ini analisis dilakukan dengan perangkat lunak AMOS (Analisis of Moment Structures) versi 22. Langkah yang ditempuh dalam melakukan analisis menggunakan SEM pada penelitian ini adalah sebagai berikut (Hair et al, 1998): Membangun Model, hasil dari tahap spesifikasi adalah diagram lintasan (path diagram) yang merupakan model hybrid atau kombinasi antara model pengukuran dan model structural.

Dalam penelitian ini terdapat 6 variabel laten dengan 26 indikator sebagaimana tertera pada desain penelitian. Analisis dilanjutkan ke tahap kedua yaitu identifikasi model matematik, model matematik yang membangun model pengukuran masingmasing variabel laten.

Analisis dilanjutkan ke tahap ketiga yaitu estimasi, estimasi dilakukan dengan teknik Full Information Techniques (FIT) yang mengestimasi seluruh sistem persamaan secara simultan dimana informasi yang 
digunakan untuk mengestimasi parameter diperoleh dari sistem persamaan pada suatu model. Metode yang digunakan adalah Maximum Likelihood (ML).

Analisis dilanjutkan ke tahap keempat yaitu uji model penelitian, uji kecocokan keseluruhan model (overall model fit), dilakukan untuk mengevaluasi secara umum derajat kecocokan atau goodness of fit (GOF) antara data dengan model menggunakan ukuran kecocokan absolut (absolut fit measures) untuk menentukan derajat prediksi model keseluruhan (Model Struktural dan Pengukuran) terhadap matriks korelasi dan kovarian. Uji kecocokan (Goodness of
Fit) mengidentifikasi seberapa baik model pengukuran variabel laten yang dispesifikasikan dalam menghasilkan matriks kovarian di antara pengukurnya (Hair et al, 1998).

Langkah terakhir adalah menguji pengaruh antar variabel dalam model struktural menggunakan uji-t yaitu membandingkan nilai critical ratio (CR) terhadap $\mathrm{t}$-tabel pada taraf uji $\mathrm{a}=5 \%$ yang ekuivalen dengan 1,96 atau membandingkan nilai probabilitas hitung (p) terhadap taraf uji penelitian (a). Jika $\mathrm{CR}>1.967$ atau $\mathrm{p}<0,05$ maka pengaruh antar variabel signifikan; Jika CR $<1.967$ atau $\mathrm{p}>0,05$ maka pengaruh antar variabel tidak signifikan.

Tabel 1. Deskripsi Variabel Penelitian

\begin{tabular}{|c|c|c|c|c|c|}
\hline Variabel/Indikator & $\begin{array}{c}\text { SLF } \\
(\geq 0,5)\end{array}$ & $\begin{array}{c}\text { CR } \\
(\geq 0,7)\end{array}$ & Keterangan & Rata-rata & Kateg \\
\hline Persepsi Iklan (IK) & & 0.80 & Reliabel & 4.0610 & Sedar \\
\hline Jangkauan (IK1) & 0.61 & & Valid & 3.9 & Sedan \\
\hline Frekuensi (IK2) & 0.80 & & Valid & 4.1 & Sedan \\
\hline - Pengaruh (IK3) & 0.85 & & Valid & 49 & Sedan \\
\hline Persepsi Promosi Penjualan & & 0.81 & Reliabel & & lan \\
\hline Kupon (PP1) & 0.72 & & Valid & 49 & dan \\
\hline - Potongan Harga (PP2) & 0.84 & & Valid & 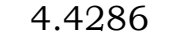 & dan \\
\hline - Price Packs (PP3) & 0.72 & & Valid & 21 & Sedan \\
\hline Persepsi Personal Selling (PS) & & 0.78 & Reli & 4. & an \\
\hline Kemampuan Komunikasi (PS1) & 0.80 & & $\mathrm{Va}$ & 29 & $S$ \\
\hline - Pengetahuan Produk (PS2) & 0.75 & & Valid & 4.1 & $\mathrm{~S}$ \\
\hline Kreatifitas (PS3) & 0.64 & & Valid & 29 & an \\
\hline - Empati (PS & 0.53 & & Valid & 97 & lan \\
\hline itas (PU) & & 0.82 & $\operatorname{Rel}$ & 4. & $\operatorname{an}$ \\
\hline - Publikasi (PU1) & 0.63 & & Valid & 4. & $\operatorname{lan}$ \\
\hline - Media Identitas (PU2) & 0.70 & & Valid & 79 & dan \\
\hline - Event (PU3) & 0.58 & & Valid & 68 & Sedan \\
\hline - Berita & 0.58 & & Valid & 24 & Sedan \\
\hline - Diseminasi (PU5) & 0.61 & & $\mathrm{Va}$ & 71 & Sedan \\
\hline - Partisipasi Aktivitas Sosial & 0.61 & & Valid & 29 & Sedan \\
\hline - Pensponsoran (PU7) & .65 & & Valid & 84 & Sedan \\
\hline Proses Keputusan Memilih (KP) & & 0.84 & Reliabel & 193 & Sedan \\
\hline - Pengenalan kebutuhan (KP1) & 0.74 & & id & 73 & Sedan \\
\hline - Kesadaran akan kebutuhan (KP2) & 0.54 & & Valid & $3 . \varepsilon$ & Sedan \\
\hline - Pencarian Informasi (KP3) & 0.64 & & Valid & 92 & Sedan \\
\hline - Pencarian alternatif (KP4) & 0.70 & & Valid & 40 & Sedan \\
\hline - Memu & 0.86 & & Valid & & Sedan \\
\hline - Perilaku pasca mer & & & Valid & 503 & Sedan \\
\hline Loyalitas (LO) & & 0.79 & Reliabel & 4.1321 & Sedan \\
\hline - Kesetiaan (LO1) & 0.76 & & Valid & 4.2857 & Sedan \\
\hline - Ketahanan (LO2) & 0.83 & & Valid & 4.1190 & Sedan \\
\hline - Mereferensikan (LO3) & 0.63 & & Valid & 3.9921 & Sedan \\
\hline
\end{tabular}

Sumber: Data penelitian yang diolah, 2020 


\section{HASIL DAN PEMBAHASAN \\ Hasil Penelitian}

Tabel 1 menunjukkan bahwa data penelitian dari kuesioner untuk variabel eksogen: iklan 3 valid, promosi penjualan 3 valid, personal selling 4 valid, publisitas 7 valid dan variabel endogen: proses keputusan 6 valid, loyalitas 3 valid. Selain itu, seluruh variabel penelitian reliabel dengan nilai CR lebih dari 0.7.

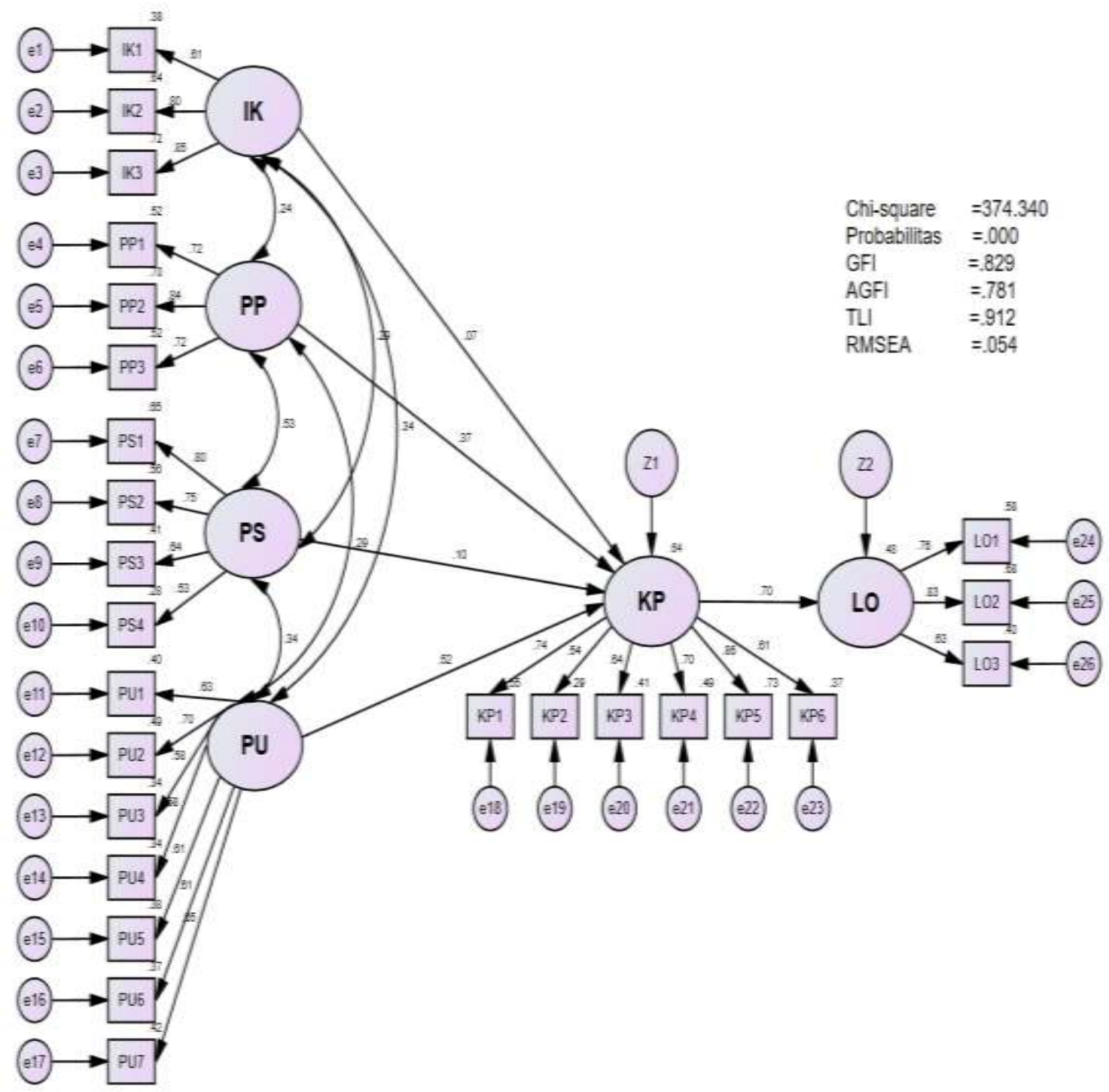

Sumber: Data penelitian yang diolah, 2020

Gambar 1. Hasil Analsisis

Variabel iklan (X1) diukur oleh jangkauan (3.9127), frekuensi (4.1349) dan pengaruh (4.1349). Hasil tersebut memperlihatkan bahwa frekuensi dan pengaruh adalah indikator yang paling kuat dalam merefleksikan variabel iklan (X1). Variabel promosi penjualan (X2) diukur oleh kupon (4.1349), potongan harga (4.4286), dan price packs (4.4921). Hasil tersebut memperlihatkan bahwa price packs adalah indikator yang paling kuat dalam merefleksikan variabel promosi penjualan (X2). Variabel personal 
selling (X3) diukur oleh kemampuan komunikasi (4.1429), pengetahuan produk (4.1111), kreatifitas (4.1429), dan empati (4.0397). Hasil tersebut memperlihatkan bahwa kemampuan komunikasi dan kreatifitas adalah indikator yang paling kuat dalam merefleksikan variabel personal selling (X3). Variabel publisitas (X4) diukur oleh publikasi (4.1190), media identitas (4.0079), event (3.8968), berita (3.9524), diseminasi (4.3571), partisipasi aktivitas sosial (4.1429), dan pensponsoran (4.1984). Hasil tersebut memperlihatkan bahwa diseminasi adalah indikator yang paling kuat dalam merefleksikan variabel publisitas (X4). Variabel proses keputusan memilih (Y) diukur oleh pengenalan kebutuhan (4.0873), kesadaran akan kebutuhan (3.8651), pencarian informasi (4.3492), pencarian alternatif (4.2540), memutuskan memilih (4.1984), dan perilaku pasca memilih (3.9603). Hasil tersebut memperlihatkan bahwa pencarian informasi adalah indikator yang paling kuat dalam merefleksikan variabel keputusan memilih (Y). Variabel loyalitas (Z) diukur oleh kesetiaan (4.2857), ketahanan (4.1190), dan mereferensikan (3.9921). Hasil tersebut memperlihatkan bahwa kesetiaan adalah indikator yang paling kuat dalam merefleksikan variabel loyalitas (Z).

Tabel 2. Model Struktural

\begin{tabular}{cccc}
\hline $\begin{array}{c}\text { Ukuran } \\
\text { Kecocokan Model }\end{array}$ & $\begin{array}{c}\text { Persyaratan } \\
\text { Model Fit }\end{array}$ & $\begin{array}{c}\text { Hasil } \\
\text { Estimasi }\end{array}$ & Tingkat Kecocokan \\
\hline $\begin{array}{c}\text { Kecocokan Absolut } \\
\text { Chi-Square } \\
\text { p-value } \\
\text { RMSEA }\end{array}$ & $\begin{array}{c}\text { Nilai yang kecil } \\
\text { p } \geq 0.05\end{array}$ & $\begin{array}{c}374.370 \\
0.000\end{array}$ & Poor Fit \\
RMR & RMSEA $\leq 0.08$ & 0.054 & Good Fit \\
GFI & RMR $\leq 0.05$ & 0.023 & Good Fit \\
Kecocokan Inkremental & GFI $\geq 0.90$ & 0.829 & Marginal Fit \\
NFI & NFI $\geq 0.90$ & 0.776 & Marginal Fit \\
NNFI & NNFI $\geq 0.90$ & 0.776 & Marginal Fit \\
CFI & CFI $\geq 0.90$ & 0.925 & Good Fit \\
IFI & IFI $\geq 0.90$ & 0.928 & Good Fit \\
AGFI & AGFI $\geq 0.90$ & 0.781 & Marginal Fit \\
\hline
\end{tabular}

Pengujian model struktural menghasilkan nilai Chi-Square sebesar 374.370 dengan p-value sebesar 0.000 termasuk dalam kategori baik (poor fit). Pengujian model juga menghasilkan nilai $\mathrm{GFI}=0.829$ dan $\mathrm{AGFI}=0.781$ yang hanya dalam kategori cukup baik (marginal fit). Namun demikian, RMSEA sebesar 0.054 dan ukuran kecocokan model lainnya dalam kategori baik (good fit) sehingga secara umum model struktural dianggap baik (good fit). 
Tabel 3. Hasil Analisis SEM

\begin{tabular}{|c|c|c|c|c|c|}
\hline Alur & Std. Estimate & $\begin{array}{l}\text { Square Std. } \\
\text { Estimate }\end{array}$ & C.R. & P. Value & Hasil \\
\hline $\mathrm{KP} \leftarrow \mathrm{IK}$ & 0.068 & 0.064 & 0.804 & 0.421 & $\begin{array}{c}\text { Tidak } \\
\text { Signifikan }\end{array}$ \\
\hline $\mathrm{KP} \leftarrow \mathrm{PP}$ & 0.365 & 0.081 & 3.545 & 0.001 & Signifikan \\
\hline $\mathrm{KP} \leftarrow \mathrm{PS}$ & 0.097 & 0.088 & 0.987 & 0.324 & $\begin{array}{c}\text { Tidak } \\
\text { Signifikan }\end{array}$ \\
\hline $\mathrm{KP} \leftarrow \mathrm{PU}$ & 0.524 & 0.166 & 4.350 & 0.001 & Signifikan \\
\hline $\mathrm{LO} \leftarrow \mathrm{KP}$ & 0.695 & 0.150 & 5.580 & 0.001 & Signifikan \\
\hline
\end{tabular}

\section{Pembahasan}

Penelitian ini menghasilkan model yang telah memenuhi kriteria sebagai model yang baik. Hal ini dapat diketahui dari terpenuhinya beberapa kriteria dalam pengujian model struktural seperti RMSEA, GFI, NFI, dan lain-lain.

Persepsi mahasiswa pada iklan (penyerapan informasi melalui iklan yang dijalankan perguruan tinggi) tidak berpengaruh terhadap proses keputusan mahasiswa memilih perguruan tinggi. Persepsi mahasiswa akan iklan (penyerapan informasi yang berasal dari kegiatan iklan) bukan faktor yang secara langsung mempengaruhi proses keputusan memilih. Baik buruknya iklan atau dapat tidaknya mahasiswa menerima informasi tentang perguruan tinggi dari iklan yang dilakukan perguruan tinggi tidak menyebabkan cepat atau lambatnya proses keputusan mahasiswa dalam memilih tempat kuliah. Temuan ini justru berseberangan dengan penelitian sebelumnya dimana iklan berpengaruh terhadap keputusan memilih (Dharmawansyah, 2014) bahkan menjadi faktor yang paling berpengaruh atau dominan (Fajarsih, 2019). Tidak adanya pengaruh iklan terhadap proses keputusan menjadi tanda tanya yang perlu mendapat perhatian dalam penelitian berikutnya. Selain itu bisa juga karena iklan saat ini banyak dilakukan menggunakan alat media yang kurang memberikan respon lebih kepada calon mahasiswa sehingga calon mahasiswa tidak memiliki daya tarik kepada iklan tersebut.

Persepsi mahasiswa pada promosi penjualan (penyerapan informasi promosi penjualan oleh calon mahasisa yang dilakukan perguruan tinggi) berpengaruh terhadap proses keputusan mahasiswa memilih perguruan tinggi dengan arah positif. Promosi penjualan yang mampu mengkomunikasikan perguruan tinggi terhadap calon mahasiswa dapat mempengaruhi kecepatan mahasiswa dalam memproses keputusan. Temuan penelitian adanya pengaruh promosi penjualan terhadap proses keputusan mahasiswa menguatkan penelitian sebelumnya (Fajarsih, 2019; Rahmawati, 2018). Gencarnya usaha terhadap promosi penjualan khususnya mengikuti berbagai kegiatan pameran, festival, stand, atau booth ke berbagai macam kegiatan di sekolah SMA sederajat. Selain itu upaya memberikan kupon atau voucher kepada mahasiswa baru akan menjadikan daya tarik yang tinggi bagi mereka.

Persepsi mahasiswa pada personal selling (penyerapan informasi melalui komunikasi yang dilakukan secara personal yang dijalankan perguruan tinggi) tidak berpengaruh terhadap proses keputusan mahasiswa memilih perguruan tinggi. Persepsi mahasiswa akan personal selling (penyerapan informasi yang berasal dari kegiatan personal selling) bukan faktor yang secara langsung mempengaruhi proses 
keputusan memilih. Baik buruknya iklan atau dapat tidaknya mahasiswa menerima informasi dari penyampaian komunikasi secara personal tidak akan membawa perubahan pada proses keputusan mahasiswa memilih perguruan tinggi. Temuan ini justru berseberangan dengan penelitian sebelumnya dimana personal selling berpengaruh signifikan terhadap variabel keputusan memilih (Maulida, 2011) bahkan menjadi faktor yang paling berpengaruh atau dominan terhadap keputusan memilih (Adeputra $\&$ Rachmawati, 2017). Tidak adanya pengaruh personal selling terhadap proses keputusan bisa jadi karena kurangnya kemampuan dari individu yang bertindak sebagai humas dalam mengkomunikasikan informasi perguruan tinggi. Tidak adanya pengaruh personal selling menjadi pertanyaan yang memberi ruang pada penelitian berikutnya.

Persepsi mahasiswa pada publisitas (penyerapan informasi publisitas oleh calon mahasiswa yang dilakukan pergurutan tinggi) berpengaruh terhadap keputusan memilih dengan arah positif. Publisitas yang dilakukan secara baik dengan memanfaatkan berbagai metode dapat membantu mahasiswa dalam proses pengambilan kputusan sehingga proses pengambilan keputusan tidak membutuhkan waktu yang panjang. Temuan penelitian adanya pengaruh publiasitas terhadap proses keputusan mahasiwa menguatkan penelitian sebelumnya (Adeputra \& Rachmawati, 2017; Maulida, 2011). Perhatian terhadap publisitas khusunya dilakukan dengan menggunakan alat media elektronik, internet maupun cetak. Selain itu perlu selalu ditambahkan pada publisitas yang berkaitan dengan kegiatan yang ada dikampus.

Kecepatan dan keyakinan dalam proses pengambilan keputusan berpengaruh terhadap loyalitas dengan arah positif. Proses keputusan yang cepat ditandai dengan tidak perlunya informasi tambahan, keyakinan dengan tidak perlu mencari mencari alternatif dan tidak adanya rasa penyesalan setelah mengambil keputusan membuat mahasiswa akan bertahan dan merekomendasikan kepada pihak lain (Susdiarto dkk, 2013; Hermawan, 2013). Perhatian terhadap keputusan memilih khususnya dipengaruhi oleh beberapa faktor seperti proses, physical evidence, referensi, motivasi, akreditasi, aktivitas mahasiswa, biaya, latar belakang sosial, reputasi, lokasi, dan promosi. Selain itu perlu selalu meningkatkan fasilitas yang ada di kampus agar mendapatkan kepercayaan penuh dari mahasiswa sehingga timbul rasa loyalitas.

\section{KESIMPULAN}

Persepsi bauran komunikasi berupa penyerapan informasi oleh mahasiswa dari kegiatan promosi penjualan dan publisitas yang dilakukan perguruan tinggi memiliki pengaruh terhadap proses keputusan mahasiswa memilih perguruan tinggi dengan arah positif. Komunikasi dalam bentuk iklan dan personal selling tidak memiliki pengaruh terhadap proses keputusan mahasiswa memilih perguruan tinggi. Proses keputusan mahasiswa yang cepat dalam memilih perguruan tinggi meningkatkan loyalitas mahasiswa pada perguruan tinggi yang dipilihnya.

Iklan dan personal selling dalam mempengaruhi proses keputusan memilih perguruan tinggi perlu ditelaah lebih lanjut pada penelitian berikutnya. Penelitian berikutnya dapat pula mencari variabel yang dapat memediasi pengaruh iklan dan personal selling terhadap keputusan memilih.

\section{DAFTAR PUSTAKA}

Adeputra, Muhamad Arif, \& Rachmawati, Indira. (2017). Pengaruh Bauran Promosi terhadap Keputusan Pembeli Produk Oppo Smartphone di Kota Bandung. e-Proceeding of Management, 4(3), 2180, Desember 2017. 
Afnina. (2011). Pengaruh Strategi Bauran Promosi terhadap Sikap Konsumen dalam Mengambil Keputusan Menjadi Mahasiswa Pada Sekolah Tinggi Ilmu Manajemen Pase Langsa. Tesis. Universitas Sumatera Utara. Program Pascasarjana.

Dewi, Nila Kasuma, dkk. (2012). Pengaruh Iklan, Citra Merek, dan Kepuasan Konsumen terhadap Loyalitas Konsumen dalam Menggunakan Vaseline Hand and Body Lotion di Kota Padang. Jurnal Manajemen dan Kewirausahaan, 3(2), 11-29, Mei 2012.

Dharmawansyah, dkk. (2014). Strategi Promosi dalam Meningkatkan Jumlah Mahasiswa pada Politeknik Negeri Media Kreatif Makassar. Jurnal Komunikasi KAREBA, 3(4), Oktober-Desember 2014.

Fahruddin, Farina Musdalifa, \& Farah Oktafani. (2015). Pengaruh Bauran Promosi terhadap Proses Keputusan Mahasiswa Memilih Telkom University (Studi pada Mahasiswa Fakultas Komunikasi dan Bisnis Telkom University Angkatan 2011 sampai dengan Angkatan 2014). e-Proceeding of Management, 2(1), 621, April 2015. ISSN: 2355-9357.

Fahrudin, Muhammad Fajar, \& Emma Yulianti. (2015). Pengaruh Promosi, Lokasi, dan Kualitas Layanan terhadap Keputusan Pembelian Nasabah Bank Mandiri Surabaya. Journal of Business and Banking, 5(1), 149-162. MayOctober.

Fajarsih, Indah Suciana. (2019). Pengaruh Advertising, Personal Selling, Sales Promotion, dan Public Relations terhadap Keputusan Memilih. Tugas Akhir. Jurusan Manajemen Bisnis Syariah Fakultas Ekonomi dan Bisnis Islam Iain Surakarta.

Hermawan, Haris. (2015). Analisis Pengaruh Bauran Pemasaran terhadap Keputusan Kepuasan dan Loyalitas Konsumen dalam Pembelian Roti Ceria di Jember. BISMA: Jurnal Bisnis dan Manajemen, 9(1), 84-93. ISSN: 2623-0879.

https://jurnal.unej.ac.id/index.p $\mathrm{hp} / \mathrm{BISMA} /$ article/view/5904

Grewal, Dhruv, \& Levy, Michael. (2014). Marketing, Fourth Edition. New York: The McGraw-Hill.

Kotler, Philip, \& Gary Armstrong. (2008). Prinsip-prinsip Pemasaran. Jakarta: PT. Erlangga

Mulyanto, Heru, \& Anna Wulandari. (2010). Penelitian: Metode dan Analisis. Semarang: CV. Agung.

Nurbani, Aep, dkk. (2019). Pengaruh Bauran Pemasaran terhadap Kepuasan dan Kepercayaan serta Dampaknya terhadap Loyalitas Konsumen. Jurnal Manajemen Kewirausahaan, 16(2).

Permatasari, Yuli. (2014). Persepsi Mahasiswa Terhadap Praktik Manajemen Laba. Skripsi. Fakultas Ekonomi Universitas Hasanuddin.

Sitorus. (2014). Pengaruh Harga dan Personal Selling terhadap Keputusan Pembelian Konsumen pada CV Sanfremy Pratama Medan. Jurnal Informatika, 2(2). https://doi.org/10.36987/inform atika.v2i2.200

Susdiarto, dkk. (2013). Pengaruh Produk dan Harga terhadap Loyalitas Konsumen dengan Keputusan Pembelian sebagai Variabel Mediasi pada PT. Pertani (Persero) Cabang Pekalongan. Jurnal Ilmiah Dinamika Ekonomi dan Bisnis, 1(2).

Tjiptono, Fandy. (2008). Strategi Pemasaran, Edisi III. Yogyakarta: CV. Andi Offset.

Wantara. Pribanus. (2015). The Relationships among Service Quality, Customer Satisfaction, and Customer Loyalty in Library Services. International Journal of Economics and Financial Issues. 